American Journal of Animal and Veterinary Sciences 6 (4): 180-186, 2011

ISSN 1557-4555

(C) 2011 F.S. Dehkordi et al., This open access article is distributed under a Creative Commons Attribution

(CC-BY) 3.0 license

\title{
Prevalence Study of Coxiella burnetii \\ in Aborted Ovine and Caprine Fetuses by Evaluation of Nested and Real-Time PCR Assays
}

\author{
Farhad Safarpoor Dehkordi \\ Young Researchers Club, Faculty of Veterinary Medicine, \\ Islamic Azad University, Shahrekord Branch, Shahrekord, Iran
}

\begin{abstract}
Problem statement: Q fever is a ubiquitous zoonosis caused by Coxiella burnetii, an obligate intracellular rickettsial organism that caused abortion and stillbirth in ruminants. Approach: The prevalence of Coxiella burnetii in Iran is essentially unknown. Its traditional diagnosis is based on culture, serology and conventional PCR. In this present study, for more sensitive and accurate detection and prevalence's determination of Coxiella burnetii in aborted Ovine and Caprine fetuses, the nested and real-time PCR methods are recommended. Results: About 98 (12.53\%) and $122(16.39 \%)$ out of 782 and 744 Ovine and Caprine aborted fetuses, were positive for presence of Coxiella burnetii by nested PCR, respectively. After LSI Taqvet Coxiella burnetii real-time PCR, it was recognized that 121 (15.47\%) and 152 (20.43\%) samples were positive for Coxiella burnetii in Ovine and Caprine aborted fetuses, respectively. Results indicated that the real-time PCR was 7 times more sensitive than the nested PCR. Statistical analysis showed significant differences about $\mathrm{P}<0.01$ between presence of Coxiella burnetii in aborted Ovine and Caprine fetuses by both nested and real-time PCR assays and P $<0.05$ between ability of nested and real-time PCR for detection of Coxiella burnetii. The $\mathrm{Ct}$ values which obtained from real-time PCR had significant differences about $\mathrm{P}<0.01$ for presence of Coxiella burnetii between aborted Ovine and Caprine fetuses. Our results indicated that Caprine is more sensitive than Ovine to Coxiella burnetii's abortion Khozestan and Gilan have the highest and Khorasan and Sistan va Baluchistan provinces have the lowest prevalence of Coxiella burnetii, respectively. Conclusion: To our knowledge, this study is the first prevalence report of direct identification of Coxiella burnetii in aborted Ovine and Caprine fetuses by evaluation of nested and real-time PCR assays in Iran. This study showed that the nested PCR for detecting Coxiella burnetii are technically time-consuming and labor-intensive.
\end{abstract}

Key words: Coxiella burnetii, aborted fetuses, nested PCR, real-time PCR

INTRODUCTION

Coxiella burnetii (C. burnetii) is a strict fastidious obligate intracellular Gram-negativebacteriumsimilar to rickettsia, which is a causative agent of important ubiquitous worldwide zoonotic infectious disease named coxiellosis or query fever ( $\mathrm{Q}$ fever) (Raoult et al., 2005). Disease can transmitted between animals and human by reservoirsinclude several species of mammals, birds and arthropods, ticks, mites, fleas, lice and flies but domestic and companion animals such as Bovine, Ovine, Caprine and Pets are the most important sources of human infection (Dupuis et al., 1987; Rauch et al., 1987; Hatchette et al., 2001). Human infections have been reported mainly in persons handling infected animals and their products (Armengaud et al., 1997).
Cattle and small ruminant, when infected, shed the desiccation-resistant organisms in urine, feces, milk and, especially, in material getting out during abortion or parturition (Arricau-Bouvery and Rodolakis, 2005; Fournier et al., 1998). High concentrations of $C$. burnetii are found in the placentas of infected animals.

Coxiellosis occurs during late pregnancy (about 15 days before term) and leading to abortion in small ruminants and stillbirth in cattle (Russo and Malo, 1981).

Because C. burnetii is highly resistant to physical as well as chemical agents, it is difficult to control once it is disseminated in the environment.

Therefore $C$. burnetii with these economic losses, need to accurate and sensitive diagnostic methods for rapid identification and elimination of persistent carriers in the herds.

Corresponding Author: Farhad Safarpoor Dehkordi, Young Researchers Club, Faculty of Veterinary Medicine, Islamic Azad University, Shahrekord Branch, Shahrekord, Iran Tel: 989365819491 Fax: 983813381892 
There are various methods for diagnosis of $C$. burnetii such as culture, serological and molecular methods. Culture method require a living host and is both time consuming and hazardous.

The diagnosis of $C$. burnetii by serological responses, which can be unspecific and unsensitive due to cross-reaction (Rousset et al., 2009) or subsensitive reactionsin samples from areas with a low or subclinical prevalence of Coxiellosis. In addition serological diagnostic methods are retrospective due to the timeframe for sero-conversion (3-4 weeks post infection), rendering them useless for timely treatment. In the other hand antibodies against $C$. burnetii may not be appear until late into the course of the disease and it is often difficult to make an early diagnosis based solely on serology for animal which present early. Since early diagnosis would be helpful for treatment of animals. In these years DNA-based methods such as PCR, nested PCR and real-time PCR as safe and useful methods have been successfully used for detection of $C$. burnetii in clinical specimens (Berri et al., 2000; 2001; Kato et al., 1998; Klee et al., 2006). The ability to detect and quantify $C$. burnetii DNA by nested and real-time PCR has dramatically enhanced diagnostic and study approaches.

Although there have been a significant number of abortions in domestic animals in Iran, there is no study on reproductive problems and the causes of abortions in ruminants in Iran in the literature so far.

So the two-fold purpose of the current study were to determined the prevalence rate of $C$. burnetii in aborted Ovine and Caprine fetuses in Iran and evaluation of nested and real-time PCR assays to detection of $C$. burnetii in abomasal contents of aborted fetuses.

\section{MATERIALS AND METHODS}

Samples: From January to May 2010, a total of 782 Ovine and 744 Caprine aborted fetuses were collected from 108 commercial Ovine and Caprine dairy herds of ten provinces of different parts of Iran (Table 1). These samples had only abomasal contents of aborted fetuses that were collected under sterile conditions and were immediately transported to the laboratory in a cooler with ice packs. All abomasal content samples were kept at $-20^{\circ} \mathrm{C}$ until processing.

DNA extraction: $C$. burnetii DNA was extracted by using a genomic DNA purification kit (Invitrogen, Paisley, U.K.) according to the manufacturer's instruction and the total DNA was measured at $260 \mathrm{~nm}$ optical density according to the method described by previous study (Sambrook and Russell, 2001).
Nested PCR assay: All oligonucleotide primers were obtained from a commercial source (Cinna Gen, Iran). The nested PCR assay used to screen for C. burnetii in aborted fetuses was designed from the nucleotide sequence of the com1 gene encoding a $27-\mathrm{kD}$ Outer Membrane Protein (OMP) as previously described (Zhang et al., 1998) and the amplification was carried according to the method described elsewhere (Fretz et al., 2007). For the nested PCR assay with primers OMP1-OMP2 and OMP3-OMP4, the first amplification was performed in a total volume of $25 \mu \mathrm{L}$ containing 5 $\mu \mathrm{L}$ of DNA sample, $0.5 \mathrm{~mm} \mathrm{MgCl} 2,0.2 \mathrm{mM}$ (each) dNTPs, $1 \mu \mathrm{m}$ primer OMP1, $1 \mu \mathrm{m}$ primer OMP2 and $0.5 \mathrm{U} /$ reaction of Taq DNA polymerase (Promega, Madison, WI). The PCR assay was performed at $94^{\circ} \mathrm{C}$ for $4 \mathrm{~min}$ and then for 30 cycles of $94^{\circ} \mathrm{C}$ for $1 \mathrm{~min}$, $56^{\circ} \mathrm{C}$ for $1 \mathrm{~min}$ and $72^{\circ} \mathrm{C}$ for $1 \mathrm{~min}$ in a DNA thermal cycler (ASTEC, Fukuoka, Japan). In the second amplification, the reaction was performed in a total volume of $25 \mu \mathrm{L}$ containing $2 \mu \mathrm{L}$ of DNA sample, 0.5 $\mathrm{mm} \mathrm{MgCl}_{2}, 0.2 \mathrm{~mm}$ (each) dNTPs, $0.82 \mu \mathrm{m}$ primer OMP3, 0.8 lmprimer OMP4 and $0.5 \mathrm{U} /$ reaction of Taq DNA polymerase (Promega, Madison, WI). The PCR assay was performed at $95^{\circ} \mathrm{C}$ for $4 \mathrm{~min}$ and then for 30 cycles of $94^{\circ} \mathrm{C}$ for $1 \mathrm{~min}, 57^{\circ} \mathrm{C}$ for $1 \mathrm{~min}$ and $72^{\circ} \mathrm{C}$ for $1 \mathrm{~min}$.

Gel electrophoresis: The PCR-amplified products (OMP1- OMP2: 501 bp; OMP3-OMP4: 438 bp) were examined by electrophoresis in a $1.5 \%$ agarose gel, stained with a $1 \%$ solution of ethidium bromide and examined under UV illumination. In this study, $C$. burnetii DNA (Serial Number: 3154; Genekam Biotechnology AG, Duisburg, Germany) and DNase free water were used as the positive and negative controls, respectively.

Real-Time PCR assay: The primer set consisted of primers trans-f (5'-GGGTAAAACGGTGGAACA ACA-3') and trans-r ACAACCCCCGAATCTCATTG- $\left.3^{\prime}\right)$. The internal probe trans-p (5'AACGATCGCGTATCTTTAACAGCGCTTG-3') was labeled with the reporter dye5-carboxyfluoroscein (FAM) on the $5^{\prime}$ end and the quencher dye $\mathrm{N}^{\prime}, \mathrm{N}^{\prime}, \mathrm{N}^{\prime}$, $\mathrm{N}^{\prime}$-tetramethyl-6-carboxyrhodamine (TAMRA) at the $3^{\prime}$ end.

Each abomasal content sample was tested using the commercial kit (targeting the repetitive transposon-like region of Coxiella burnetii), LSI Taqvet Coxiella burnetii_ (Laboratoire Service International, Lissieu, France) assay, according to the manufacturer's instructions. The negative control sample used was 
DNase RNase free water. The external positive control used was a solution containing $10^{5}$ Coxiella burnetiil mL (provided by UR INRA IASP, Nouzilly, France). DNA extraction was performed directly from $200 \mu \mathrm{L}$ of abomasal contents. All Real time PCRs reactions were carried out using a Rotor Gene 6000 instrument (Corbett Research). For positive samples (having a typical amplification curve), the results are given in $\mathrm{Ct}$ (cycle threshold) values. Only the samples presenting a typical amplification curve with a $\mathrm{Ct}$ below 40 were considered positive.

Sensitivity of nested and real-time PCR assays: Solutions of purified $C$. burnetii were prepared ranging from $1 \times 106$ to 1 microorganisms/100 $\mu \mathrm{L}$. DNA was extracted by a genomic DNA purification kit (Invitrogen, Paisley, U.K.), according to the instruction manual. About $200 \mu \mathrm{L}$ of the solution at microorganism concentration were used and the extracted DNA was dissolved in $100 \mu \mathrm{l}$ of distilled water. About $3 \mu \mathrm{L}$ of the DNA solution were used in the nested and real-time PCR assays. Results are shown as number of microorganisms in one PCR-tube (microorganisms/PCR-tube) and in $200 \mu \mathrm{L}$ of sample (microorganisms/sample).

Statistical analysis: Data were transferred to Microsoft Excel spreadsheet (Microsoft Corp., Redmond, WA, USA) for analysis. Using SPSS 18.0 statistical software (SPSS Inc., Chicago, IL, USA), ANOVA test analysis were performed and differences were considered significant at values of $\mathrm{P}<0.05$.

\section{RESULTS}

In this study a total of 782 Ovine and 744 Caprine aborted fetuses from 108 Ovine and Caprine dairy herds of ten provinces of Iran, were tested by nested and realtime PCR for presence of C. burnetii.

Results indicated that 98 out of 782 aborted Ovine fetuses $(12.53 \%)$ and 122 out of 744 aborted Caprine fetuses $(16.39 \%)$ were positive for presence of $C$. burnetii by nested PCR (Table 1).

After Real-time PCR, from a total of 782 and 744 aborted Ovine and Caprine fetuses, C. burnetii gene were distinguished in $121(15.47 \%)$ and 152 (20.43\%)samples, respectively (Table 1).

Sensitivity was compared between the nested and real-time PCR assays in the detection of $C$. burnetii DNA. The nested PCR assay with two pairs of primers, OMP1 and 2 and OMP3 and 4 detected 63 microorganisms/PCR-tube, equivalent to $2 \times 103$ microorganisms/sample, whereas the real-time PCR assay with the trans-f (5'GGGTAAAACGGTGGAACA ACA-3') and trans-r (5'-ACAACCCCCGAATCTCATTG-3') primers, detected 9 microorganisms/PCR-tube equivalent to $2 \times 102$ microorganisms/sample (data not shown), indicating that the real-time PCR assay was 7 times more sensitive than the nested PCR assay.

Table 1: Distribution of $C$. burnetii in ten provinces of Iran by using nested PCR and real-timePCR. This study showed that $C$. burnetii in Caprine, has a more severe effects than Ovine

\begin{tabular}{|c|c|c|c|c|c|c|}
\hline \multirow[b]{2}{*}{ Provinces } & \multicolumn{2}{|c|}{ No. of samples } & \multicolumn{2}{|c|}{ Nested PCR (\%) } & \multicolumn{2}{|c|}{ Real-Time PCR (\%) } \\
\hline & Ovine & Caprine & Ovine & Caprine & Ovine & Caprine \\
\hline \multirow[t]{2}{*}{ Isfahan } & 89 & 81 & 5.00 & 10.00 & 6.00 & 12.00 \\
\hline & & & -5.61 & -12.34 & -6.74 & -14.81 \\
\hline \multirow[t]{2}{*}{ Gorgan } & 57 & 52 & 7.00 & 14.00 & 10.00 & 27.00 \\
\hline & & & -12.28 & -26.92 & -17.54 & -29.67 \\
\hline \multirow[t]{2}{*}{ Khozestan } & 83 & 77 & 18.00 & 21.00 & 22.00 & 25.00 \\
\hline & & & -21.68 & -27.27 & -26.50 & -32.46 \\
\hline \multirow[t]{2}{*}{ Khorasan } & 78 & 70 & 2.00 & 11.00 & 3.00 & 13.00 \\
\hline & & & -2.56 & -15.71 & -3.84 & -18.57 \\
\hline \multirow[t]{2}{*}{ Sistan va balochestan } & 71 & 75 & 3.00 & 4.00 & 5.00 & 6.00 \\
\hline & & & -4.22 & -5.33 & -7.04 & -8.00 \\
\hline \multirow[t]{2}{*}{ Kerman } & 79 & 68 & 6.00 & 5.00 & 7.00 & 6.00 \\
\hline & & & -7.59 & -7.35 & -8.86 & -8.82 \\
\hline \multirow[t]{2}{*}{ Gilan } & 92 & 91 & 19.00 & 23.00 & 23.00 & 22.00 \\
\hline & & & -20.65 & -25.27 & -25.00 & -42.30 \\
\hline \multirow[t]{2}{*}{ Fars } & 103 & 96 & 14.00 & 7.00 & 16.00 & 9.00 \\
\hline & & & -13.59 & -7.29 & -15.53 & -9.37 \\
\hline \multirow[t]{2}{*}{ Kordestan } & 75 & 64 & 13.00 & 15.00 & 16.00 & 18.00 \\
\hline & & & -17.33 & -23.43 & -21.33 & -28.12 \\
\hline \multirow[t]{2}{*}{ Ilam } & 55 & 72 & 11.00 & 12.00 & 13.00 & 14.00 \\
\hline & & & -20.00 & -16.66 & -23.63 & -19.44 \\
\hline \multirow[t]{2}{*}{ Total } & 782 & 744 & 98.00 & 122.00 & 121.00 & 152.00 \\
\hline & & & -12.53 & -16.39 & -15.47 & -20.43 \\
\hline
\end{tabular}


Statistical analysis showed significant differences about $\mathrm{P}<0.01$ between aborted Ovine and Caprine fetuses for presence of $C$. burnetii by both nested and real-time PCR assays and $\mathrm{P}<0.05$ between nested PCR and real-time PCR for detection of $C$. burnetii. In the other hand, The $\mathrm{Ct}$ values which obtained from realtime PCR had significant differences about $\mathrm{P}<0.01$ between aborted Ovine and Caprine fetuses.

So this study showed the higher accuracy and sensitivity of real-time PCR than nested PCR to detection of $C$. burnetiiin aborted Ovine and Caprine fetuses. Therefore the prevalence rates of $C$. burnetiiin aborted Ovine and Caprine fetuses are $12.78 \%$ and $19.08 \%$ respectively.

In this present study, Khozestan $(26.5 \%)$ and Gilan $(42.3 \%)$ provinces have the highest and Khorasan $(3.84 \%)$ and Sistan va balochestan $(8 \%)$ provinces have the lowest prevalence rates of $C$. burnetiiin aborted Ovine and Caprine fetusesin Iran, respectively (Table 1). Our results indicated that Caprine is more sensitive than Ovine to Coxiella burnetii's abortion (20.43\% in Caprine versus $15.47 \%$ in Ovine).

Results showed the high prevalence rate of $C$. burnetiiin animals of Iran.

\section{DISCUSSION}

In the majority of cases, $C$. burnetii's abortion occurs at the end of gestation without specific clinical signs until abortion is imminent, as observed with brucellosis or chlamydiosis. Aborted fetuses appear normal but infected placentas exhibit intercotyledonary fibrous thickening and discolored exudates, which are not specific to $\mathrm{Q}$ fever. A severe inflammatory response is observed in the myometrium and the stroma adjacent to the placentomal area during gestation in goats.

Because $C$. burnetii may be shed by other routes such as milk, feces, urine, placenta, or birth fluids, testing animal based on only abomasal contents of aborted fetus samples can be lead to misclassify the status of the animal (Guatteo et al., 2006). In fact, the differences between the prevalence of $C$. burnetii in ovine and caprine abomasal contents of aborted fetus samples found in this study may be because of the different routes of shedding $C$. burnetii present in these animals. Ovine shed $C$. burnetii mainly in feces and vaginal mucus, whereas Caprine excrete $C$. burnetii in their vaginal discharges, feces and milk (Rodolakis et al., 2007). Furthermore, the infected animals may not persistently shed C. burnetii. Shedding of $C$. burnetii by infected animals occurs mainly during parturition and lactation. Therefore, detection of $C$. burnetii in abomasal contents of Ovine and Caprine aborted fetuses not depends on the sampling time. In addition to above, abomasal contents of aborted fetuses contain all of the vaginal, placental and even birth fluids and it is an advantage of abomasal content samples than urine, feces and even milk samples for detection of $C$. burnetii.

In addition to the route of infection, the inoculums size is affect the expression of $C$. burnetii infection.

The $C$. burnetii'sabortion rate can range from 3-80\% of pregnant animals (Berri et al., 2000; 2002; Palmer et al., 1983; Zeman et al., 1989). High abortion rates are rarely observed, except in some caprine herds (Palmer et al., 1983). Often, the number of animals those abort in the flock may not be enough to alert the farmer and human clinical cases often reveal the infection of the flock (Berri et al., 2000). Ewes shed more and longer in vaginal discharges than goats and can shed bacteria at subsequent pregnancies (Berri et al., 2003).

The epidemiology of Q-fever in Iran is essentially unknown and to the authors' knowledge, the prevalence rate of $C$. burnetii in ruminant's aborted fetuses in Iran has never been reported but there are some studies that reported detection of $C$. burnetii in various clinical samples in Iran (Khalili et al., 2010; Khalili and Sakhaee, 2009).

The prevalence rate of $C$. burnetii in aborted Ovine in Iran $(15.47 \%)$, is higher than northern Spain $(9 \%)$ (Oporto et al., 2006) and Italy (10\%) (Masala et al., 2004) but is lower than Netherlands (up to 80\%) (Roest et al., 2011) and the prevalence rates of $C$. burnetii in aborted Caprine fetuses in Iran $(20.43 \%)$ are higher than United Kingdom (25\%) (Jones et al., 2010) and lower than Netherlands (up to 80\%) (Roest et al., 2011) and Italy (21.5\%) (Parisi et al., 2006).

This present study showed that nested PCR and real-time PCR assays can be used extensively as fast, safe and accurate diagnostic methods to detection of $C$. burnetii in aborted Ovine and Caprine fetuses but the real-time PCR assay is faster and more sensitive and accurate than nested PCR to detection of C. burnetii. Previous studies suggested the high sensitivity, specificity and accuracy of molecular methods such as PCR (Arricau-bouvery et al., 2006), nested PCR (Fretz et al., 2007), PCR-Enzyme linked immune sorbent assay (PCR-ELISA) (Muramatsu et al., 1997) and RealTime PCR (Guatteo et al., 2007) to detection of $C$. burnetii in clinical specimens.

Since, PCR has been developed for the detection of C. burnetii for a wide variety of clinical samples such as serum (Zhang et al., 1998), blood (Kato et al., 1998), urine (Vaidya et al., 2008), feces (Berri et al., 2000), milk (Willems et al., 1994) vaginal tissue (Cairns et al., 2007) and semen (Milazzo et al., 2001). 
The real-time PCR assay that use in this study, is more accurate, sensitive and faster than ELISA and conventional PCR to detection of $C$. burnetii. In addition, the real-time PCR assay has some advantages compared to the nested PCR; it is an important diagnostic tool yielding reliable and reproducible results, does not require post-PCR analysis (gel electrophoresis, hybridization) and the risk of cross contamination is limited than nested PCR method but the real-time PCR is more expensive than nested PCR. This study showed that the nested PCR method for detecting $C$. burnetii is technically time-consuming and labor-intensive than real-time PCR assay.

The real-time PCR assay that use in this study can simplify the procedure by testing presumptive $C$. burnetii genome taken directly from abomasal contents of aborted fetus samples. Using the LSI Taqvetassay offers specificity higher than that of gel electrophoresis and finally this real-time PCR can substantially decrease the risk of carryover contamination.

The controls of the coxiellosis in cases with abortions are very difficult. Because the vaccine was not able to prevent neither abortions nor bacterial shedding neither in milk, vaginal secretions and nor in feces (Souriau et al., 2003). Only Antibiotic treatments with tetracyclines can be used to reduce the number of abortions and the quantities of $C$. burnetii shed at parturition (Behymer et al., 1977).

Although no extensive prevalence study was undertaken, the results of this study indicate that the prevalence rates of $C$. burnetii's abortions are high in Ovine and Caprine in Iran.

\section{CONCLUSION}

To our knowledge, this study is the first prevalence survey of $C$. burnetii in aborted Ovine and Caprine fetuses of Iran by evaluation of nested PCR and realtime PCR assays. This present study suggested that real-time PCR is more sensitive and more accurate than nested PCR and can use as a safe, fast and thrust full diagnostic method for detection of $C$. burnetii's in aborted fetuses.

\section{ACKNOWLEDGEMENT}

The researchers would like to thank Hassan Momtaz for the sincere help in performing technical parts of the project.

\section{REFERENCES}

Armengaud, A., N. Kessalis, J.C. Desenclos, E. Maillot and P. Brousse et al., 1997. Urban outbreak of Q fever, Briancon, France, March to June 1996. Euro Surveill, 2: 12-13. PMID: 12631827
Arricau-Bouvery, N. and A. Rodolakis, 2005. Is Q Fever an emerging or re-emerging zoonosis? Vet. Res., 36: 327-349. DOI: 10.1051/vetres:2005010

Arricau-Bouvery, N., Y. Hauck, A. Bejaoui, D. Frangoulidis and C.C. Bodier et al., 2006. Molecular characterization of Coxiella burnetii isolates by infrequent restriction site-PCR and MLVA typing. BMC. Microbiol., 6: 38-38. PMID: 16640773

Behymer, D., R. Ruppanner, H.P. Riemann, E.L. Biberstein and C.E. Franti, 1977. Observation on chemotherapy in cows chronically infected with Coxiella burnetii (Q fever). Folia. Vet. Lat, 7: 6470. PMID: 885444

Berri, M., A. Souriau, M. Crosby and A. Rodolakis, 2002. Shedding of Coxiella burnetii in ewes in two pregnancies following an episode of Coxiella abortion in a sheep flock. Vet. Microbiol., 85: 5560. PMID: 11792492

Berri, M., A. Souriau, M. Crosby, D. Crochet and P. Lechopier et al., 2001. Relationships between the shedding of Coxiella burnetii, clinical signs and serological responses of 34 sheep. Vet. Rec., 148: 502-505. DOI: $10.1136 / v r .148 .16 .502$

Berri, M., E. Rousset, J.L. Champion, N. ArricauBouvery and P. Russo et al., 2003. Ovine manure used as a garden fertiliser as a suspected source of human Q fever. Vet. Rec., 153: 269-270. DOI: 10.1136/vr.153.9.269

Berri, M., K. Laroucau andA. Rodolakis, 2000a. The detection of Coxiella burnetii from ovine genital swabs, milk and fecal samples by the use of a single touchdown polymerase chain reaction. Vet. Microbiol., 72: 285-293. PMID: 10727838

Cairns, K., M. Brewer and M.R. Lappin, 2007. Prevalence of Coxiella burnetii DNA in vaginal and uterine samples from healthy cats of northcentral Colorado. J Feline Med. Surg., 9: 196-201. PMID: 17208030

Dupuis, G., J. Petite, O. Peter and M. Vouilloz, 1987. An important outbreak of human $Q$ fever in a Swiss Alpine valley. Int. J. Epidemiol., 16: 282287. PMID: 3301708

Fournier, P.E., T.J. Marrie and D. Raoult, 1998. Diagnosis of Q fever. J. Clin. Microbiol., 36: 1823-1834.

Fretz, R., W. Schaeren, M. Tanner and A. Baumgartner, 2007. Screening of various foodstuffs for occurrence of Coxiella burnetii in Switzerland. Int. J. Food Microbiol., 116: 414-418. PMID: 17434220 
Guatteo, R., F. Beaudeau, A. Joly and H. Seegers, 2007. Assessing the within-herd prevalence of Coxiella burnetii milk-shedder cows using a real-time PCR applied to bulk tank milk. Zoonoses. Public. Health, 54: 191-194. PMID: 17542961

Guatteo, R., F. Beaudeau, M. Berri, A. Rodolakis and A. Joly et al., 2006. Shedding routes of Coxiella burnetii in dairy cows: Implications for detection and control. Vet. Res., 37: 827-833. PMID: 16973121

Hatchette, T.F., R.C. Hudson, W.F. Schlech, N.A. Campbell and J.E. Hatchette et al., 2001. Goatassociated Q fever: A new disease in Newfoundland. Emerg. Infect. Dis., 7: 413-419. PMID: 11384518

Jones, R.M., D.F. Twomey, S. Hannon, J. Errington and G.C. Pritchard et al., 2010. Detection of Coxiella burnetii in placenta and abortion samples from British ruminants using real-time PCR. Vet. Rec., 167: 965-967. PMID: 21262712

Kato, K., Y. Arashima, S. Asai, Y. Furuya and Y. Yoshida et al., 1998. Detection of Coxiella burnetii specific DNA in blood samples from Japanese patients with chronic nonspecific symptoms by nested polymerase chain reaction. FEMS. Immunol. Med. Microbiol., 21: 139-144. PMID: 9685003

Khalili, M. and E. Sakhaee, 2009. An update on a serologic survey of Q fever in domestic animals in Iran. Am. J. Trop. Med. Hyg., 80: 1031-1032. PMID: 19478271

Khalili, M., N. Shahabi-Nejad and M. Golchin, 2010. Q fever serology in febrile patients in Southeast Iran. Trans. Roy. S. Trop. Med. Hyg., 104: 623-624 PMID: 20627331

Klee, S.R., J. Tycaka, H. Ellerbrok, T. Franz and S. Linke et al., 2006. Highly sensitive real-time PCR for specific detection and quantification of Coxiella burnetii. BMC. Microbiol., 6: 2-2. DOI: 10.1186/1471-2180-6-2

Masala, G., R. Porcu, G. Sanna, G. Chessa and G. Cillara et al., 2004. Occurrence, distribution, and role in abortion of Coxiella burnetii in sheep and goats in Sardinia, Italy. Vet. Microbial., 99: 301305. DOI: 10.1016/j.vetmic.2004.01.006

Milazzo, A., R. Hall, P.A. Storm, R.J. Harris, and . Winslow et al., 2001. Sexually transmitted Q fever. Clin. Infect. Dis., 33: 399-402 PMID: 11438911

Muramatsu, Y., T, Yanase, T. Okabayashi, H. Ueno and C. Morita, 1997. Detection of Coxiella burnetii in cow's milk by PCR-enzyme-linked immunosorbent assay combined with a novel sample preparation method. Applied Environ. Microbiol., 63: 21422146. PMID: 9172331
Oporto, B., J.F. Barandika, A. Hurtado, G. Aduriz and B. Moreno et al., 2006. Incidence of ovine abortion by Coxiella burnetii in northern Spain. Ann. N. Y. Acad. Sci., 1078: 498-501. DOI: 10.1196/annals.1374.095

Palmer, N.C., M. Kierstead, D.W. Key, J.C. Williams and M.G. Peacock et al., 1983. Placentitis and abortion in goats and sheep in Ontario caused by Coxiella burnetii. Can. Vet. J., 24: 60-61 PMCID: PMC1790252

Parisi, A., R. Fraccalvieri, M. Cafiero, A. Miccolupo and I. Padalino et al., 2006. Diagnosis of Coxiella burnetii-related abortion in Italian domestic ruminants using single-tube nested PCR. Vet. Microbial., 118: 101-106. PMID: 16891064

Raoult, D., T.J. Marrie and J. Mege, 2005. Natural history and pathophysiology of Q fever. Lancet. Infect. Dis., 5: 219-226. DOI: 10.1016/S14733099(05)70052-9

Rauch, A.M., M. Tanner, R.E. Pacer, M.J. Barrett and C.D. Brokopp et al., 1987. Sheep-associated outbreak of Q fever, Idaho. Arch. Intern. Med., 147: 341-344. PMID: 3813754

Rodolakis, A., M. Berri, C. Hechard, C. Caudron and A. Souriau et al., 2007. Comparison of Coxiella burnetii shedding in milk of dairy bovine, caprine, and ovine herds. J. Dairy Sci., 90: 5352-5360. PMID: 18024725

Roest, H.I., R.C. Ruuls, J.J. Tilburg, M.H. NabuursFranssen and C.H. Klaassen et al., 2011. Molecular Epidemiology of Coxiella burnetii from Ruminants in Q Fever Outbreak, the Netherlands. Emerg. Infect. Dis., 17: 668-675. PMID: 21470457

Rousset, E., M. Berri, B. Durand, P. Dufour and M. Prigent et al., 2009. Coxiella burnetii shedding routes and antibody response after outbreaks of $\mathrm{Q}$ fever-induced abortion in dairy goat herds. Applied Environ. Microbiol., 75: 428-433. DOI: 10.1128/ AEM.00690-08

Russo, P. and N. Malo, 1981. Q fever in the French department of Vienne. Kinetics of antibodies and abortion [Coxiella burneti, goat]. Recl. Med. Vet., 157: 585-589.

Sambrook, J. and D.W. Russell, 2001. Molecular Cloning: A Laboratory Manual. 3 rd $_{\text {Edn., CSHL }}$ Press, New York, ISBN: 0879695773.

Souriau, A., N. Arricau-Bouvery, C. Bodier and A. Rodolakis, 2003. Comparison of the efficacy of Q fever vaccines against Coxiella burnetii experimental challenge in pregnant goats. Ann. N. Y. Acad. Sci., 990: 521-523. PMID: 12860684 
Vaidya, V.M., S.V.S. Malik, S. Kaur, S. Kumar and S.B. Barbuddhe, 2008. Comparison of PCR, immunofluorescence assay and pathogen isolation for diagnosis of $\mathrm{q}$ fever in humans with spontaneous abortions. J. Clin. Microbiol., 46: 2038-2044. PMID: 18448698

Willems, H., D. Thiele, R. Frohlish-Ritter and H. Krauss, 1994. Detection of Coxiella burnetii in cow's milk using the polymerase chain reaction (PCR). Zentralbl. Veterinarmed. B, 41: 580-587. PMID: 7740857
Zeman, D.H., C.A. Kirkbride, P. Leslie-Steen and J.R. Duimstra, 1989. Ovine abortion due to Coxiella burnetii infection. J. Vet. Diagn. Invest, 1: 178180. DOI: $10.1177 / 104063878900100218$

Zhang, G.Q., S.V. Nguyen, H. To, M. Ogawa and A. Hotta et al., 1998. Clinical evaluation of a new PCR assay for detection of Coxiella burnetii in human serum samples. J. Clin. Microbiol., 36: 7780. PMID: 9431924 